\title{
DIGITALCOMMONS
}

$@$ WAYNESTATE -

Wayne State University

\section{U5a1 Mitochondrial DNA Haplotype Identified in Eneolithic Skeleton from Shatar Chuluu, Mongolia}

\author{
Leland L. Rogers \\ Indiana University - Bloomington \\ William Honeychurch \\ Yale University \\ Chunag Amartuvshin \\ Institute of Archaeology, Academy of Sciences, Ulaanbaatar, Mongolia \\ Frederika A. Kaestle \\ University of Illinois - Chicago
}

Follow this and additional works at: https://digitalcommons.wayne.edu/humbiol_preprints

\section{Recommended Citation}

Rogers, Leland L.; Honeychurch, William; Amartuvshin, Chunag; and Kaestle, Frederika A., "U5a1

Mitochondrial DNA Haplotype Identified in Eneolithic Skeleton from Shatar Chuluu, Mongolia" (2020).

Human Biology Open Access Pre-Prints. 160.

https://digitalcommons.wayne.edu/humbiol_preprints/160

This Brief Communication is brought to you for free and open access by the WSU Press at DigitalCommons@WayneState. It has been accepted for inclusion in Human Biology Open Access Pre-Prints by an authorized administrator of DigitalCommons@WayneState. 


\title{
Brief Communication: U5a1 Mitochondrial DNA Haplotype Identified in Eneolithic Skeleton from Shatar Chuluu, Mongolia
}

\section{Running Title: U5a1 mtDNA identified in Eneolithic Mongolia}

Leland L. Rogers1,2,4, William Honeychurch2, Chunag Amartuvshin3, and Frederika A. Kaestle1

${ }_{1}$ Department of Anthropology, Indiana University, Bloomington, Indiana, USA

2 Department of Anthropology, Yale University, New Haven, Connecticut, USA

3 Institute of Archaeology, Academy of Sciences, Ulaanbaatar, Mongolia

4 Department of Anthropology, University of Illinois, Chicago, Illinois, USA

\begin{abstract}
The mitochondrial haplotype U5a1 was identified from an Eneolithic grave associated with the Afanasievo archaeological culture in Bayankhongor Province, Erdenetsogt Township, at the site of Shatar Chuluu. This is the earliest appearance of a mtDNA haplotype associated with modern European populations on the Mongol Steppe. This evidence demonstrations that people with "western" mtDNA lived on the Mongol Steppe east of the Altai Mountains before the Bronze Age and refutes the notion that the Altai Mountains were a substantial barrier to gene flow and definitively expands the acknowledged range of the Afanasievo archaeological culture.
\end{abstract}

Key Words: Afanasievo, Mongolia, mitochondrial DNA, Eneolithic, U5a1

\section{Introduction}

It has been argued that the Altai Mountain range in western Mongolia had been a significant barrier for culture and gene flow until the late Bronze Period in the middle of the first millennium BCE (Pullyblank 2000; Keyser-Tracqui et al 2003; Ricaut et al 2004; González-Ruiz et al 2012). New evidence suggests that "western" people were inhabiting the eastern Eurasian steppe of central Mongolia as early as the Eneolithic period (circa late 4th millennium BCE). This study sequenced the first hypervariable (HV1) region of the mitochondrial DNA (mtDNA) of three individuals from Bayankhongor Province, Mongolia. Mitochondrial DNA is inherited solely through the mother, and so is used to trace matrilines, and is commonly used for comparative population studies (Pakendorf \& Stoneking 2005; Relethford 2012). Bayankhongor Province is in west central Mongolia and includes the southern edge of the Khangai Mountain range, substantial portions of the Gobi desert-steppe, as well as the eastern edge of the Altai mountain range. Erdenetsogt Township is located near the northeast border of Bayankhongor Province along the Tüi River, near to where it meets Övörkhangai and Arkhangai provinces (Map 1). According to the skeletal archive catalog at the National University of Mongolia, the Shatar Chuluu site (also known as Shatar Uul), was first excavated in 1971 by archaeologists Navaan and Volkov, revealing several Neolithic, Eneolithic and Bronze Age burials (Volkov 1995). The burial mound, from which the present sample was recovered, is associated with the Eneolithic Afanasievo archaeological culture (circa. 3100$2500 \mathrm{BCE}$ ) based on its stone surface construction, the arrangement of the human burial, and diagnostic decorated ceramics (Novgorodova 1989; Polyakov et al 2017; Poliakov et al 2018). The Afanasievo archaeological culture was first identified in southern Siberia in the Minusinsk Basin and northern Altai mountain range and can be found throughout the Mongolian Altai (Gryaznov 1969, Kovalev \& Erdenebaatar 2009). Shatar Chuluu is located along the border of forest-steppe and mountain biomes, and 
the people associated with the burial were possibly early pastoralists with limited seasonal mobility, similar to Afanasievo communities of the west. However, it is important to note that although Afanasievo style ceramics and burial types were identified at Shatar Chuluu, no faunal materials or other evidence for lifeways in this region have been reported (Novgorodova 1989:81-86).

The mtDNA haplogroups: A, B, C, D, F, G, M, Y and Z, are generally considered "eastern” Eurasian, and are currently found in high frequencies in the populations of East Asia, Central Asia and Siberia; mtDNA haplogroups: H, HV, I, J, K, N, R, T, U, V, W and X, are commonly considered to be "western" Eurasian, as they are currently found in highest frequency in the populations throughout Europe and southwest Asia (Derenko et al 2007; Keyser-Tracqui 2006; Derbeneva 2009; Schurr \& Pipes 2011; Gonzalez-Ruiz et al 2012; Zhao et al 2015; Gubina et al 2016). The modern population of the Mongol Steppe has physical features predominantly associated the eastern Eurasian populations and according to previous studies a mtDNA gene pool composed of 86.4\% "eastern" Eurasian mtDNA haplotypes (Kolman et al 1996; Yao et al 2004; Derenko et al 2007).

Prior to the Eneolithic period, archaeologists are still piecing together an understanding of the diverse lifeways of populations inhabiting Mongolia during the Late Neolithic from circa 4000-3000 BCE. It is still the case that not a great deal is known about these earlier groups except that most Neolithic artifacts and site locations suggest a predominantly forager culture with emphasis on broad spectrum subsistence in resource rich wetlands and nearby lowland environments (Günchinsüren \& Bazargür 2009; Janz et al 2017). Wild ungulates of many sorts roamed the region and, although there is currently only indirect evidence, domesticated bovids (cattle, sheep and goats) were most likely introduced to the region during the Eneolithic and Early Bronze Age periods (Honeychurch 2017; Matuzeviciute et al 2016). The initial presence of herd animals on the eastern steppe contributed to the hunter-herder subsistence systems as foraging communities gradually obtained both domestic animals and knowledge of their upkeep (Janz et al 2017; Honeychurch 2017; Frachetti 2012). Habitation sites from the Eneolithic are invariably found beside rivers, oases or ancient river beds (Vybornov 2011). The Afanasievo archaeological culture has been genetically and culturally linked with the late Eneolithic and Early Bronze Age Yamnaya archaeological culture (ca. 3300-2500 BCE) located on the Pontic-Caspian Steppe as far east as the Ural River (Hollard et al 2018; Allentoft et al 2015). A long-standing explanation for the arrival of domestic herd animals and new material culture and burial forms in the Altai mountains at circa $3100 \mathrm{BC}$ has argued for migrations of Yamnaya groups between the Urals and the Altai, a distance of more than 2000 $\mathrm{km}$ (Anthony 2007). Due to a series of complications in radiocarbon chronology and rather sparse evidence for Yamnaya groups between the two mountain ranges, the migration model has been critiqued and challenged (Frachetti 2012; Poliakov et al 2018). The present study provides yet another opportunity to evaluate this migration-based hypothesis for Yamnaya-Afanasievo connections.

This sample has provided the earliest ancient DNA evidence from the Mongol steppe region. Currently, no Eneolithic period or earlier human DNA testing of samples from the Mongol Steppe could be located for comparison; although González-Ruiz's team has sequenced three samples from the Mongolian Altai Mountains, all of these samples have mtDNA haplotypes that belong to the "eastern" haplogroup D (2012). The data from the present study establish a new ante quem date for the presence of people carrying "western" mtDNA haplogroups onto the Mongol Steppe, east of the Altai Mountain range.

\section{Materials and Contexts}

Pre-print version. Visit http://digitalcommons.wayne.edu/humbiol/ after publication to acquire the final version. 
This study consists of three samples that were labeled as "Neolithic" in the National University of Mongolia (NUM) archives (AT26 occipital fragment; AT27 left metacarpal 3; AT30 rib). These samples were graciously provided by Professor Tumen Dashtseveg, with permission from the Mongolian government. Despite the labeling, these samples were considered to be the only Pre-Bronze samples in the NUM human skeletal archives from the central Mongol Steppe. All three samples were found in the province of Bayankhongor and, based on the interpretation of excavators, were thought to be associated with the Afanasievo archaeological culture (Volkov 1995). Two of the samples were from Erdenetsogt Township, from a site identified as Shatar Chuluu, excavated in 1971 (Grave 2:AT26 and Grave 5:AT27). The third sample (AT30) was from Galuut Township with no mention of a specific site name.

For reasons made clear below, we provide a brief overview of the archaeological contexts at Shatar Chuluu but not for the Galuut site. Shatar Chuluu is an archaeological complex located at 2000 masl atop a high river terrace on the east bank of the Tui River (Tuin Gol). The site comprises monuments and burials from the Bronze Age, the Early Iron Age, and the period of the Turkic Empires and so has been a place of ritual activity for the past 3500 years at least. Afanasievo style burials with diagnostic decorated pottery were discovered along the terrace edge and excavated by the 1971 Mongol-Russian Archaeological Project (Volkov 1980). A total of three burials arranged north to south were identified based on their large circular surface features made with stone fill and ranging in diameter from 6.5 to 10 $\mathrm{m}$ and between 0.4 and $0.7 \mathrm{~m}$ in height. As these surface features were cleared, archaeologist recovered pottery fragments having a coarse brown fabric and decorated with multiple incised chevrons (Figure 1). These decorations as well as the shape and size of the original ceramic jars were immediately recognized as diagnostic Afansievo forms similar to those know from the Altai, Minusinsk, and Tuva regions of South Siberia (Volkov 1980). Beneath each of these stone features excavators exposed individual burial pits ranging from 0.7 to $1.7 \mathrm{~m}$ in depth and each containing a single human skeleton oriented either to the east or west and interred in a supine position with legs bent to one side (Figure 1). In each case, the skeletons retained traces of ocher coloring that had been originally applied during the burial ceremony, another trait associated with Afanasievo burial practices. However, the Shatar Chuluu burials also have notable differences from other Afanasievo burial grounds including a lack of additional burial furnishings besides ceramics and no inclusion of animal offerings. These similarities and differences in burial practice have led the most recent expert study of Shatar Chuluu to conclude that the site represents a variant of Afanasievo traditions most similar to those known from Tuva (Tsybiktarov 2002:117).

Of these three contexts from which skeletal material was obtained, two from Shatar Chuluu and one from Galuut, relatively little archaeological information is available. This is due both to the rarity of the small number of publications describing these sites, as well as to the general lack of laboratory facilities and analytical capacity during the 1970s. Returning to these curated materials in storage at the National University of Mongolia and the Institute of Archaeology provides promising opportunities for modern analyses to finally produce the kinds of information needed to understand these early burial sites. The genetic and chronological results we provide here brings us one step closer to that goal. Samples from the Shatar Chuluu and Galuut burials were extracted and sequenced using Sanger PCR methods (Sanger et al. 1977). Material from the samples that were succesfully haplotyped was sent to the Center for Applied Isotope Studies at the University of Georgia for radiocarbon dating.

\section{Laboratory Protocols}

\section{CONTAMINATION CONTROL}

Pre-print version. Visit http://digitalcommons.wayne.edu/humbiol/ after publication to acquire the final version. 
Contamination with exogenous DNA is a serious issue to consider when working with ancient samples and thorough measures must be taken to reduce the probability of contamination as much as possible and to detect contamination should it occur (Kaestle and Horsburgh 2002; Pääbo et al 2004; Gilbert et al 2005; Kemp et al 2007). Samples used in this study were processed in the dedicated limited access aDNA laboratory of Dr. Frederika Kaestle at Indiana University, Bloomington (IUB). Established protocols for reducing contamination were strictly followed and all PCR amplification and post-PCR analyses occurred in a laboratory in a different building (Tamariz et al 2006; Ballantyne et al 2015). Negative (no sample) controls were processed in parallel during each DNA extraction with each set of samples extracted, and all Polymerase Chain Reactions (PCR) also included two negative (no sample) controls for every set, in addition to the extraction control, to detect any contamination that may have occurred in the laboratory. Results for samples were confirmed with a minimum of two identical sequences from three separate extractions. To guarantee removal of previously amplified products that could result in carry-over contamination, a dNTP mix containing uracil instead of thymine was used in all PCR amplifications, and each amplification was pre-digested with AmpErase ${ }^{\mathrm{TM}}$ Uracil N-glycosylase (Thermo Fisher Scientific) (Longo et al 1990). The only researcher after selection from the skeletal archives that handled the samples and was present in the aDNA laboratory during extractions and amplifications tested into the $\mathrm{Z}$ mtDNA haplogroup, and thus could not have been a source of contamination.

\section{ANCIENT DNA EXTRACTION}

DNA extraction from the ancient skeletal samples was conducted in Dr. Kaestle's aDNA laboratory located in the Institute for Molecular Biology at Indiana University, Bloomington, with established protocols using the Thermo Fisher Scientific Geneclean ${ }^{\circledR}$ for ancient DNA ${ }^{\text {TM }}$ kit (Kemp \& Smith 2005; Raff et al 2006; Kemp et al 2007; Raff 2010; Ballantyne et al 2015). The protocol used 0.4-0.5mg of a sample for each extraction $(0.2-0.4 \mathrm{mg}$ were used in secondary and tertiary extractions when sample amounts were limited). One negative (no sample) control was added for every sample set. After protein digestion in the ProK solution, the $15 \mathrm{ml}$ tubes were centrifuged for 10 minutes at $14000 \mathrm{rpm}$ and the supernatant was transferred to a new $15 \mathrm{ml}$ tube. Any remaining samples were then stored at $-80^{\circ} \mathrm{C}$. Three hundred $\mu \mathrm{l}$ of glass milk (silica) solution from the Geneclean ${ }^{\circledR}$ for ancient DNA ${ }^{\mathrm{TM}}$ kit and $800 \mu \mathrm{l}$ of $5 \mathrm{M}$ Guanidine Thiocyanate (GITC) solution was added to the supernatant, which was then rocked at room temperature for a minimum of 30 minutes to bind the DNA in solution to the glass milk. From here, the $15 \mathrm{ml}$ tube was centrifuged for 10 minutes at $14000 \mathrm{rpm}$ to collect the glass milk at the bottom, and the supernatant was discarded. From this point resuspension and purification was done according to the protocols from the Geneclean ${ }^{\circledR}$ for ancient DNA ${ }^{\mathrm{TM}}$ kit. Each sample was extracted three separate times with several month periods between extractions to confirm results. No negative controls from the extraction groups showed subsequent amplification.

\section{ANCIENT DNA AMPLIFICATION}

Sanger Polymerase Chain Reaction (PCR) amplification of the extracts was conducted using three sets of primers covering most of the HV1 region of the mitochondrial DNA (see Table 1 for primers and amplicon). Presumably due to excellent preservation conditions in Mongolia (cold, dry and saline), extractions were consistently amplified, and thus it was possible to compile high-quality sequences spanning np16038-16356 from the mtDNA of the samples. Amplification was performed with PCRx Enhancer (Thermo Fisher Scientific), 10x Invitrogen PCR Buffer (Thermo Fisher Scientific), Invitrogen

Pre-print version. Visit http://digitalcommons.wayne.edu/humbiol/ after publication to acquire the final version. 
$25 \mathrm{mM} \mathrm{MgCl} 2$ (Thermo Fisher Scientific), $20 \mathrm{mg} / \mathrm{ml}$ Bovine Serum Albumin (BSA) (Thermo Fisher Scientific), $10 \mathrm{mM}$ dNTPs, $20 \mathrm{uM}$ primers, Invitrogen hot-start Platinum ${ }^{\circledR}$ Taq (Thermo Fisher Scientific), Applied Biosystems AmpErase ${ }^{\mathrm{TM}}$ Uracil N-glycosylase (Thermo Fisher Scientific) and nuclease-free $\mathrm{H}_{2} \mathrm{O}$. Each PCR was performed with $3 \mu \mathrm{l}$ of extracted sample as template in a $25 \mu \mathrm{l}$ volume, $0.2 \mathrm{ml}$ thin-walled tube. At least one negative (no extract) amplification control was included with every six sample extractions, including the extraction negative control. After PCR set-up the sample tubes were sealed and transferred from the aDNA laboratory to the modern DNA laboratory for the amplification reaction in either an MJ Research PTC-200 thermal cycler or a Bio-Rad C1000 thermal cycler. For each sample 13.13 $\mu$ l DNA free $\mathrm{H}_{2} \mathrm{O}, 2.5 \mu 1$ PCR Enhancer, 2.5 $\mu 1$ 10x PCR Buffer, 1.5 $\mu 1$ MgCL2, 0.4 $\mu 1$ dNTPs, $0.52 \mu 1 \mathrm{BSA}, 0.4 \mu 1$ of each primer, $0.4 \mu 1$ PlatinumTaq, $0.25 \mu 1$ AmpErase ${ }^{\mathrm{TM}}$ Uracil N-glycosylase and $3 \mu 1$ of extracted aDNA template were added for a $25 \mu 1$ reaction volume per $0.2 \mathrm{ml}$ tube. The following cycling parameters were used for amplification reactions: initial soak at $95^{\circ} \mathrm{C}$ for 2 minutes: followed by 40 cycles of: denature at $94^{\circ} \mathrm{C}$ for 30 seconds: anneal at $50^{\circ} \mathrm{C}$ (for np16038-16213) or $57^{\circ} \mathrm{C}$ (for np1620916356) for 30 seconds: extend at $72^{\circ} \mathrm{C}$ for 30 seconds: followed by a final extension at $72^{\circ} \mathrm{C}$ for 5 minutes. This was followed by a hold at $4^{\circ} \mathrm{C}$ until sample was moved to a $-20^{\circ} \mathrm{C}$ freezer to await gel electrophoresis. Amplification success was assessed through ultraviolet visualization after agarose gel electrophoresis with ethidium bromide stain before sequencing.

\section{SEQUENCING}

Following electrophoretic detection of amplification, each fragment was sequenced in both directions using ABI Big Dye v3.1 chemistry (Thermo Fisher Scientific) on an Applied Biosystems 3730 automated sequencing system at the Indiana Molecular Biology Institute. Amplicons were purified using the manufacturer's protocol for the QIAquick PCR Purification Kit ${ }^{\mathrm{TM}}$ (Qiagen), then sequenced using the manufacturer's protocol for ABI Big Dye v3.1. Each extraction, amplification, and sequencing reaction was repeated at least twice following at least a month's interval, so that different batches of reagents were used. Resulting electropherograms were assessed using Geneious 6.1.8 software (Biomatters Limited) and aligned against the revised Cambridge Reference Sequence (rCRS) (Anderson et al 1981, Andrews et al 1999, Genbank Accession Number NC_012920). A consensus sequence was generated from at least two identical sequences from three extractions per individual using Geneious 6.1.8. SNP differences between the consensus sequences and the rCRS were used to determine mtDNA haplogroup and haplotype. Confirmed sequences were submitted to Genbank (Accession Number NC_XXXXXX) (Benson et al 2013). Mitochondrial DNA haplogroup assignments were determined through the HaploGrep2 algorithm (Kloss-Brandstatter et al 2011; Weissensteiner et al 2016) based on PhyloTree17, and back traced for accuracy (van Oven 2015).

\section{Results}

Sequence from the two individuals excavated at the Shatar Chuluu site (AT26 and AT27) from Erdenetsogt Township revealed diagnostic polymorphisms that allowed mtDNA haplogroup determination. These were confirmed through three separate extractions for each sample and at least two separate amplifications of each extraction conducted over a period of three years. The third sample (AT30), from Galuut Township, sequenced successfully, but the polymorphisms it exhibited in the HV1 region were too basal for haplogroup assignment and further diagnostics failed to produce reproducible results. Samples from the Shatar Chuluu site provided confirmed haplotypes for the sequencing of np16058-16356 (discounting 16192-16209 of primer overlap) of HV1 of the mtDNA. The sequence of

Pre-print version. Visit http://digitalcommons.wayne.edu/humbiol/ after publication to acquire the final version. 
the individual from Grave 2 (AT26) of Shatar Chuluu matched rCRS (H2a2a haplotype) and the sequence of the individual from Grave 5 (AT27) showed polymorphisms at np 16256, 16270 and 16278, and thus was assigned to the U5a1 haplotype. Human bone material from the samples AT26 and AT27 were sent to Dr. Alexander Cherkinsky at the Center for Applied Isotope Studies, the University of Georgia, for radiocarbon dating. Sample AT27 produced a calibrated radiocarbon date of 3090-3054 and 3031-2920 BCE, 95.4\% probability (4390 +/-20 BP, UGAMS-35431) (Figure 2). However, after radiocarbon dating, AT26 proved to have been from the early Iron Age period (346-206 BCE, 95.4\% probability, 2230 +/-20 BP UGAMS-38794), possibly an intrusive burial and clearly not related to the Afanasievo Eneolithic time frame.

\section{Discussion}

Identifying the AT27 individual from the Mongol Steppe with an U5a1 haplotype places the arrival of "western" matrilines no later than the Eneolithic. Both the genetic results and dating can be considered in accordance with the current hypothesis of a migration into eastern Eurasian regions by people associated with the Yamnaya archaeological culture (ca. 3300-2500 BCE). Although the Shatar Chuluu site so far provides no additional evidence about subsistence practices, the Yamnaya-Afanasievo relationship is presumed to mark the diffusion of cattle, sheep and goat pastoralism into East Asia via the Altai mountains (Gryaznov 1969; Anthony 2007; Svyatko et al 2013; Polyakov et al 2017; Hollard et al 2018; however cf. Frachetti 2012). It has been suggested that the U5 haplogroup developed in southeastern Europe as it has been found to be the most common clade $(64 \%)$ of the U haplogroup in Mesolithic and Neolithic Europe (Malyarchuk 2004; Malyarchuk et al 2005; Haak et al 2005, 2010; Lee et al 2012; Juras et al 2018). According to a study by Malyarchuk et al (2010), the U5a1 haplogroup has a coalescence date of $16,200 \mathrm{ybp}$, shortly after the last glacial maximum. The U5 haplogroup has been found in the populations of the central European Neolithic Linearbandkeramik (LBK) archaeological culture (ca. 5700-4800 BCE) from central Europe, and in the Eneolithic-Early Bronze Age Yamnaya (Pit Grave) archaeological culture (ca. 3300-2500 BCE), which has been connected with the Afanasievo archaeological culture (ca. 3100-2500 BCE) of the Minusinsk Basin and Altai Mountains (Mallory 1989; Dolukhanov et al 2005; Anthony 2007; Bentley et al 2012; Brown 2014; Allentoft et al 2015; Fowler et al 2015; Gomart et al 2015; Haak et al 2015; Nikitin et al 2017; Hollard et al 2018). The U5 haplogroup is often considered to be a genetic component of a European hunter-gatherer population and is occasionally referenced as a companion haplogroup to the Y-Chromosomal R1a haplogroup, the diffusion of which has often been attributed to the Scythians, the people recorded by Herodotus' The Histories in the fifth century BCE of the Pontic Steppe region (De Sélincourt 2003; Juras et al 2017). U5a1 has been previously identified in individuals from the Afanasievo archaeological culture in the Altai Mountains, the Yamnaya archaeological culture in the Ukraine, as well as the later Pazyryk archaeological culture of the $4_{\text {th }}$ and 3 rd centuries BCE also found in the Altai region associated by some archaeologists with Scythian groups (Rudenko 1970; Pilipenko et al 2010; Juras et al 2018), and has also been seen in the Neolithic period Transbaikalia (Molodin et al 2012). Modern Eurasian populations outside of Europe with a relatively high frequency of U5 include the populations of the southern Siberian Tubalar and Yeniseian Ket (Sukernik et al 2012), the Khakassian of southern Siberia, Tuvans and Kazakhs, and some among the Shorians another small population also found in southern Siberia (Gubina et al 2013). The U5 haplotype is also found in most Central Asian populations (Comas et al 2004; Kivisild et al 1999). U haplogroups are very rare in East Asian populations today.

Pre-print version. Visit http://digitalcommons.wayne.edu/humbiol/ after publication to acquire the final version. 
The discovery of a "western" European mitochondrial lineage on the Mongol Steppe from the Eneolithic pushes back East-West genetic admixture in the region significantly, and conclusively shows that "western" genes were on the Mongol Steppe, east of the Altai Mountains, from at least the Eneolithic period. This refutes the premise that western peoples had not expanded east of the Altai range before the Iron Age, which, as mentioned above, has been a general supposition among scholars (Pullyblank 2000; Keyser-Tracqui et al 2003; Ricaut et al 2004; González-Ruiz et al 2012; de Barros Damgaard et al 2018). The discovery of a "western" mtDNA haplotype in an individual from the Eneolithic period on the Mongol Steppe must now be factored into modeling for post LGM migrations in Eurasia and East Asia. The mtDNA haplotype U5a1 and calibrated radiocarbon date result of 3054-2920 BCE are consistent with what is currently known about the Afanasievo archaeological record and ancient genetics, thus hypotheses that assume little to no western migration before the Bronze Age east of the Altai Mountains, must be reconsidered in this light. How porous the Altai Mountains were, whether there had been a "western" population in the region long before this sample, and the size of the "western" population in the region at the time of the AT27 individual's burial at Shatar Chuluu, cannot be determined given current data. However, the presence of a considerable "western" genetic population in the Khangai mountain range during the Eneolithic period likely contributed to the number and frequency of burials postdating this site with individuals carrying "western" mtDNA haplotypes (Rogers 2016). The dating and the mtDNA haplogroup of the AT27 sample are congruous with previous Afanasievo archaeological culture sites and associated human remains (Kovalev \& Erdenebaatar 2009; Svyatko et al 2009; Allentoft et al 2015), which suggests that the range of the Afanasievo archaeological culture should be extended to include the southern Khangai Mountains of central Mongolia.

This result supports the initial 1971 assessment by Mongolian and Russian archaeologists as to the cultural designation of at least one of the excavated contexts at Shatar Chuluu. Based on this, we would agree with Volkov's (1995) argument that indeed the Afanasievo archaeological culture extended as far as some parts of west central Mongolia. In addition to this discovery by Navaan and Volkov, other archaeologists have documented similar burials and ceramics in Bayan Olgii provice of western Mongolia and in Arkhangai province just to the north of the Shatar Chuluu site (Kovalev and Erdenabaatar 2009:152; Novgorodova 1989:81-86). Of these two sites, only the western context has been radiocarbon dated to circa 2800/2700 BC but neither context has had genetic analysis of human remains although we expect that the present study will encourage such research to be carried out.

Clearly the greatest weakness of this study is its sample size $(N=1)$; however, this does not invalidate the positive findings. Clearly many more samples must be sequenced before any reliable estimates can be made concerning an overall genetic make-up of the Eneolithic population of central Mongolia. Evidence from additional genetic analysis in the region (Rogers 2016) demonstrates that by the Late Bronze Age $42.3 \%$ of the population carried "western" mtDNA haplogroups. This suggests that the "western" component in the regional population during the Eneolithic was most likely significant. While success rates in this study were $100 \%$ for sequencing the $298 \mathrm{bp}$ section tested, the sample size is obviously too small for significant population comparison studies. Full genome sequencing on samples AT27 and AT30 would provide additional information on the ancestry of these two samples, and additional samples dating to the Eneolithic period from the Mongol Steppe and Khangai Mountain range would be an important contribution to the better understanding of the ancient population dynamics in central Mongolia.

\section{Acknowledgements}

Pre-print version. Visit http://digitalcommons.wayne.edu/humbiol/ after publication to acquire the final version. 
The Authors would like to first and foremost thank Professor Tumen Dashtseveg for allowing access to the National University of Mongolia's human skeletal archives. We would also like to thank the American Center for Mongolian Studies for initial funding, the Department of Anthropology at the Indiana University-Bloomington for research funding, and the Whitney and Betty MacMillan Center for international and Area Studies for their additional support.

\section{Literature Cited}

Achilli, A., Rengo, C., Magri, C., Battaglia, V., Olivieri, A., Scozzari, R., Cruciani, F., Zeviani, M., Brien, E., Carelli, V., Moral, P., Dugoujon, J.M., Roostalu, U., Loogväli, E.L., Kivisild, T., Bandelt, H. J., Richards, M., Villems, R., Santachiara-Benerecetti, A. S., Semino, O., \& Torroni, A. (2004). The Molecular Dissection of mtDNA Haplogroup H Confirms That the FrancoCantabrian Glacial Refuge Was a Major Source for the European Gene Pool. American Journal of Human Genetics, 75, 910-918.

Allentoft, M. E., Sikora, M., Sjögren, K. G., Rasmussen, S., Rasmussen, M., Stenderup, J., Damgaard, P. B., Schroeder, H., Ahlström, T., Vinner, L., Malaspinas, A.S., Margaryan, A., Higham, T., Chivall, D., Lynnerup, N., Harvig, L., Baron, J., Della Casa, P., Dabrowski, P., Duffy, P. R., Ebel, A. V., Epimakhov, A., Frei, K., Furmanek, M., Gralak, T., Gromov, A., Gronkiewicz, S., Grupe, G., Hajdu, T., Jarysz, R., Khartanovich, V., Khokhlov, A., Kiss, V., Kolár, J., Kriiska, A., Lasak, I., Longhi, C., McGlynn, G., Merkevicius, A., Merkyte, I., Metspalu, M., Mkrtchyan, R., Moiseyev, V., Paja, L., Pálfi, G., Pokutta, D., Pospieszny, Ł., Price, T.D., Saag, L., Sablin, M., Shishlina, N., Smrčka, V., Soenov, V. I., Szeverényi, V., Tóth, G., Trifanova, S. V., Varul, L., Vicze, M., Yepiskoposyan, L., Zhitenev, V., Orlando, L., Sicheritz-Pontén, T., Brunak, S., Nielsen, R., Kristiansen, K., \& Willerslev, E. (2015). Population Genomics of Bronze Age Eurasia. Nature, 522, 167-172.

Anthony, D. W. (2007). The Horse, the Wheel, and Language. Princeton, NJ: Princeton University Press.

Ballantyne, K. N., Salemi, R., Guarino, F., Pearson, J. R., Garlepp, D., Fowler, S., \& van Oorschot, R. A. H. (2015). DNA contamination minimisation - finding an effective cleaning method. Australian Journal of Forensic Sciences, 47(4), 428-439.

Benson, D. A., Clark, K., Karsch-Mizrachi, I., Lipman, D. J., Ostell, J., \& Sayers, E. W. (2013). GenBank. Nucleic Acids Research, 42, D32-37.

Bentley, R. A., Bickle, P., Fibiger, L., Nowell, G. M., Dale, C. W., Hedges, R. E. M., Hamilton, J., Wahl, J., Francken, M., Grupe, G., Lenneis, E., Teschler-Nicola, M., Arbogast, R. M., Hofmann, D., \& Whittle, A. (2012). Community differentiation and kinship among Europe's first farmers. Proceedings of the National Academy of Sciences of the United States of America, 109(24), 9326-9330.

Brown, K. A. (2014). Women on the Move: The DNA Evidence for Female Mobility and Exogamy in Prehistory. J. Leary (Ed.). Past Mobilities: Archaeological Approaches to Movement and Mobility (pp. 155-174). Surrey, England: Ashgate.

Clark, P. U., Dyke, A. S., Shakun, J. D., Carlson, A. E., Clark, J., Wohlfarth, B., Mitrovica, J. X., Hostetler, S. W., \& McCabe, A. M. (2009). The Last Glacial Maximum. Science, 325, 710-714.

Pre-print version. Visit http://digitalcommons.wayne.edu/humbiol/ after publication to acquire the final version. 
Comas, D., Plaza, S., Wells, R.S., Yuldaseva, N., Lao, O., Calafell, F. \& Bertranpetit, J. (2004). Admixture, Migrations, and Dispersals in Central Asia: Evidence from Maternal DNA Lineages. European Journal of Human Genetics, 12, 495-504.

de Barros Damgaard, P., Martiniano, R., Kamm, J., Moreno-Mayar, J. V., Kroonen, G., Peyrot, M., Barjamovic, G., Rasmussen, S., Zacho, C., Baimukhanov, N., Zaibert, V., Merz, V., Biddanda, A., Merz, I., Loman, V., Evdokimov, V., Usmanova, E., Hemphill, B., Seguin-Orlando, A., Yediay, F. E., Ullah, I., Sjögren, K. G., Iversen, K. H., Choin, J., de la Fuente, C., Ilardo, M., Schroeder, H., Moiseyev, V., Gromov, A., Polyakov, A., Omura, S., Senyurt, S. Y., Ahmad, H., McKenzie, C., Margaryan, A., Hameed, A., Samad, A., Gul, N., Khokhar, M. H., Goriunova, O. I., Bazaliiskii, V. I., Novembre, J., Weber, A. W., Orlando, L., Allentoft, M. E., Nielsen, R., Kristiansen, K., Sikora, M., Outram, A. K., Durbin, R., \& Willerslev, E. (2018). The first horse herders and the impact of early Bronze Age steppe expansions into Asia. Science, 10.1126/science.aar7711.

Derbeneva, O. (2009). Estimated Worldwide Haplotype Frequencies (\%). Accessed September 2016. http://www.mitomap.org/foswiki/bin/view/MITOMAP/HaplogroupMarkers.

Derenko, M., Malyarchuk, B., Grzybowski, T., Denisova, G., Dambueva, I., Perkova, M., Dorzhu, Ch., Luzina, F., Lee, H. K., Vanecek, T., Villems, R., \& Zarkhov, I. (2007). Phylogeographic Analysis of Mitochondrial DNA in Northern Asian Populations. American Journal of Human Genetics, 81, 1025-1041.

de Sélincourt, A. (2003). Herodotus: The Histories. London, UK: Penguin.

Dolukhanov, P., Shukurov, A., Gronenborn, D., Sokoloff, D., Timofeev, V., \& Zaitseva, G. (2005). The chronology of Neolithic dispersal in Central and Eastern Europe. Journal of Archaeological Science, 32, 1441-1458.

Fowler, C., Harding, J., \& Hofmann, D. (Ed.) (2015) The Oxford Handbook of Neolithic Europe. Oxford $\&$ New York: Oxford University Press.

Frachetti, M. D. (2012). Multiregional Emergence of Mobile Pastoralism and Nonuniform Institutional Complexity across Eurasia. Current Anthropology, 53(1), 2-38.

Gilbert, M. T. P., Bandelt, H. J., Hofreiter, M., \& Barnes, I. (2005). Assessing ancient DNA studies. Trends in Ecology and Evolution, 20(10), 541-544.

Gomart, L., Hachem, L., Hamon, C., Giligny, F., \& Ilett, M. (2015). Household integration in Neolithic villages: A new model for the Linear Pottery Culture in west-central Europe. Journal of Anthropological Archaeology, 40, 230-249.

González-Ruiz, M., Santos, C., Jordana, X., Simón, M., Lalueza-Fox, C., Gigli, E., Aluja, M. P., \& Malgosa, A. (2012). Tracing the Origin of the East-West Population Admixture in the Altai Region (Central Asia). PLoS ONE, 7(11), e48904. doi:10.1371/journal.pone.0048904.

Gryaznov, M. P. (1969). The Ancient Civilization of Southern Siberia: An Archaeological Adventure. J. Hogarth (Trans.). New York: Cowles Book Company.

Pre-print version. Visit http://digitalcommons.wayne.edu/humbiol/ after publication to acquire the final version. 
Gubina, M. A., Damba, L. D., Babenko, V. N., Romaschenko, A. G., \& Voevoda, M. I. (2013). Haplotype Diversity in mtDNA and Y-Chromosome in Populations of Altai-Sayan Region. Russian Journal of Genetics, 49(3), 329-343.

Gubina, M. A., Kulikov, I. V., Babenko, V. N., Chikisheva, T. A., Romashenko, A. G., Voevoda, M. I., \& Molodin, V. I. (2016). The Dynamics of the Composition of mtDNA Haplotypes of the Ancient Population of the Altai Mountains from the Early Bronze Age (3rd Millennium BC) to the Iron

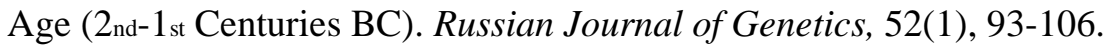

Günchinsüren, B., \& Bazargür, D. (2009). An Outline of Neolithic Studies in Mongolia. J. Bemmann, H. Parzinger, E. Pohl, \& D. Tseveendorzh (Eds.). Current Archaeological Research in Mongolia. (pp. 47-52). Bonn, Germany: Rheinische Friedrich-Wilhelms-Universität Bonn.

Haak, W., Forster, P., Bramanti, B., Matsumura, S., Brandt, G., Tänzer, M., Villems, R., Renfrew, C., Gronenborn, D., Alt, K. W., \& Burger, J. (2005). Ancient DNA from the First European Farmers in 7500-Year-Old Neolithic Sites. Science, New Series, 310(5750), 1016-1018.

Haak, W., Balanovsky, O., Sanchez, J. J., Koshel, S., Zaporozhchenko, V., Adler, C. J., Der Sarkissian, C. S. I., Brandt, G., Schwarz, C., Nicklisch, N., Dresely, V., Fritsch, B., Balanovska, E., Villems, R., Meller, H., Alt, K. W., Cooper, A., \& the Genographic Consortium (2010). Ancient DNA from European Early Neolithic Farmers Reveals Their Near Eastern Affinities. PLoS Biology. 8(11), e1000536. doi:10.1371/journal.pbio.1000536.

Haak, W., Lazaridis, I., Patterson, N., Rohland, N., Mallick, S., Llamas, B., Brandt, G., Nordenfelt, S., Harney, E., Stewardson, K., Fu, Q. M., Mittnik, A., Bánffy, E., Economou, C., Francken, M., Friedrich, S., Pena, R. G., Hallgren, F., Khartanovich, V., Khokhlov, A,, Kunst, M., Kuznetsov, P., Meller, H., Mochalov, O., Moiseyev, V., Nicklisch, N., Pichler, S. L., Risch, R., Guerra, M. A. R., Roth, C., Szécsényi-Nagy, A., Wahl, J., Meyer, M., Krause, J., Brown, D., Anthony, D., Cooper, A., Alt, K. W., \& Reich, D. (2015). Massive migration from the steppe was a source for Indo-European languages in Europe. Nature, 522, 207-211.

Hollard, C., Zvénigorosky, V., Kovalev, A., Kiryushin, Y., Tishkin, A., Lazaretov, I., Crubézy, E., Ludes, B., \& Keyser, C. (2018). New genetic evidence of affinities and discontinuities between bronze age Siberian populations. American Journal of Physical Anthropology, 167, 97-107.

Honeychurch, W. (2015). Inner Asia and the Spatial Politics of Empire: Archaeology, Mobility, and Culture. New York, Heidelberg, Dordrecht \& London: Springer.

Honeychurch, W. (2017). The Development of Cultural and Social Complexity in Mongolia. J. Habu, P. Lape, and J. Olsen, (Eds). Handbook of East and Southeast Asian Archaeology. (pp. 513-532). New York, USA: Springer Publications.

Juras, A., Chyleński, M., Ehler, E., Malmström, H., Żurkiewicz, D., Włodarczak, P., Wilk, S., Peška, J., Fojtík, P., Králík, M., Libera, J., Bagińska, J., Tunia, K., Klochko, V.I., Dabert, M., Jakobsson, M. \& Kośk, A. (2018). Mitochondrial Genomes Reveal an East to West Cline of Steppe Ancestry in Corded Ware Populations. Scientific Reports 8: 11603. DOI:10.1038/s41598-01829914-5.

Pre-print version. Visit http://digitalcommons.wayne.edu/humbiol/ after publication to acquire the final version. 
Kaestle, F. A., \& Horsburgh, K. A. (2002). Ancient DNA in anthropology: Methods, applications, and ethics. American Journal of Physical Anthropology, 119(S35), 92-130.

Kemp, B. M., \& Smith, D. G. (2005). Use of bleach to eliminate contaminating DNA from the surface of bones and teeth. Forensic Science International, 154, 53-61.

Kemp, B. M., Monroe, C., \& Smith, D. G. (2007). Extraction and Analysis of DNA from Archaeological Specimens. Archaeological chemistry: analytical techniques and archaeological interpretation. (pp. 78-98). Washington D.C., USA: American Chemical Society.

Keyser-Tracqui, C., Crubézy, E., \& Ludes, B. (2003). Nuclear and Mitochondrial DNA Analysis of a 2,000-Year-Old Necropolis in the Egyin Gol Valley of Mongolia. American Journal of Human Genetics, 73, 247-260.

Keyser-Tracqui, C., Crubézy, E., Pamzsav, H., Varga, T., \& Ludes, B. (2006). Population Origins in Mongolia: Genetic Structure Analysis of Ancient and Modern DNA. American Journal of Physical Anthropology, 131, 272-281.

Kivisild, T., Bamshad, M.J., Kaldma, K., Metspalu, M., Metspalu, E., Reidla, M., Laos, S., Parik, J., Watkins, W.S., Dixon, M.E., Papiha, S.S., Mastana, S.S., Mir, M.R., Ferak, V. \& Villems, R. (1999). Deep Common Ancestry of Indian and Western-Eurasian mitochondrial DNA Lineages. Current Biology, 9[22]: 1331-1334.

Kloss-Brandstätter, A., Pacher, D., Schönherr, S., Weissensteiner, H., Binna, R., Specht, G., \& Kronenberg, F. (2011). HaploGrep: a fast and reliable algorithm for automatic classification of mitochondrial DNA haplogroups Human Mutation, 32(1), 25-32. doi: 10.1002/humu.21382. Epub 2010 Nov 16.

Kolman, C. J., Sambuughin, N., \& Berminham, E. (1996). Mitochondrial DNA Analysis of Mongolian Populations and Implications for the Origin of New World Founders. Genetics, 142, 1321-1334.

Kovalev, A. A., \& Erdenebaatar, D. (2009). Discovery of New Cultures of the Bronze Age in Mongolia according to Data obtained by the International Central Asian Archaeological Expedition. Current Archaeological Research in Mongolia. J. Bemmann, H. Parzinger, E. Pohl, \& D. Tseveendorzh (Eds.). Current Archaeological Research in Mongolia. (pp. 149-170). Bonn, Germany: Rheinische Friedrich-Wilhelms-Universität Bonn.

Lee, E. J., Makarewicz, C., Renneberg, R., Harder, M., Krause-Kyora, B., Müller, S., Ostritz, S., FehrenSchmitz, L., Schreiber, S., Müller, J., von Wurmb-Schwark, N., \& Nebel, A. (2012). Emerging Genetic Patterns of the European Neolithic: Perspectives from a Late Neolithic Bell Beaker Burial Site in Germany. American Journal of Physical Anthropology, 148, 571-579.

Liu, L., \& Chen, X. C. (2012). The Archaeology of China: from the Late Paleolithic to the Early Bronze Age. Cambridge, England: Cambridge University Press.

Longo, M. C., Berninger, M. S., \& Hartley, J. L. (1990). Use of uracil DNA glycosylase to control carryover contamination in polymerase chain reactions. Gene, 93, 125-128.

Mallory, J. P. (1989). In Search of the Indo-Europeans, Language, Archaeology and Myth. London, England: Thames and Hudson.

Pre-print version. Visit http://digitalcommons.wayne.edu/humbiol/ after publication to acquire the final version. 
Malyarchuk, B. A. (2004). Differentiation of the Mitochondrial Subhaplogroup U4 in the Populations of Eastern Europe, Ural, and Western Siberian: Implication to the Genetic History of the Uralic Populations. Genetika, 40(11), 1549-1556.

Malyarchuk, B., Derenko, M., Grzybowski, T., Perkova, M., Rogella, U., Vanecek, T., \& Tsybovsky, I. (2010). The Peopling of Europe from the Mitochondrial Haplogroup U5 Perspective. PloS ONE, 5(4), e10285.

Matuzeviciute, G. M., Kiryushin, Y. F., Rakhimkhanova, S. Z., Svyatko, S., Tishkin, A. A., \& O’Connell, T. C. (2016), Climatic or Dietary change? Stable isotope analysis of Neolithic-Bronze Age populations from the Upper $\mathrm{Ob}$ and Tobol River Basins. The Holocene, I-II. doi:10.1177/0959683616646843.

Miller, A. V., Usmanova, E., Logvin, V., Kalieva, S., Shevnina, I., Logvin, A., Kolbina, A., Suslov, A., Privat, K., Haas, K., \& Rosenmeier, M. (2014). Subsistence and social change in central Eurasia: stable isotope analysis of populations spanning the Bronze Age transition. Journal of Archaeological Science, 42, 525-538.

Molodin, V.I., Pilipenko A.S., Romaschenko A.G., Zhuravlev A.A., Trapezov R.O., Chikisheva, T.A. \& Pozdnyakov, D.V. (2012). "Human migrations in the southern region of the West Siberian Plain during the Bronze Age: Archaeological, palaeogenetic and anthropological data", in: Elke Kaiser, Joachim Burger and Wolfram Schier (Eds.), Population Dynamics in Prehistory and Early History. New Approaches by Using Stable Isotopes and Genetics. Berlin, Boston: De Gruyter, pp. 93-112.

Nikitin, A. G., Ivanova, S., Kiosak, D., Badgerow, J., \& Pashnick, J. (2017). Subdivisions of haplogroup $\mathrm{U}$ and $\mathrm{C}$ encompass mitochondrial DNA lineages of Eneolithic-Early Bronze Age Kurgan populations of western North Pontic steppe. Journal of Human Genetics, 62, 605-613.

Pääbo, S., Poinar, H., Serre, D., Jaencke-Despres, V., Hebler, J., Rohland, N., Kuch, M., Krause, J., Vigilant, L., \& Hofreiter, M. (2004). Genetic Analyses from Ancient DNA. Annual Review of Genetics, 38, 645-679.

Pakendorf, B., \& Stoneking, M. (2005). Mitochondrial DNA and Human Evolution. Annual Review of Genomics and Human Genetics, 6, 165-183.

Pilipenko, A. S., Romaschenko, A. G., Molodin, V. I., Parsinger, H., \& Kobzev, V. F. (2010). Mitochondrial DNA studies of the Pazyryk people (4th to 3 rd centuries BC) from northwestern Mongolia. Archaeological and Anthropological Sciences, 2, 231-236.

Poliakov, A. V., Svyatko, S. V., \& Stepanova, N. F. (2017). НОВЫЕ ДАННЫЕ ПО РАДИОУГЛЕРОДНОЙ ХРОНОЛОГИИ ПАМЯТНИКОВ АФАНАСЬЕВСКОЙ КУЛЬТУРЫ АЛТАЯ. ТРУДЫ V (ХХІ) ВСЕРОССИЙСКОГО АРХЕОЛОГИЧЕСКОГО СЪЕЗДА, Том III, 62-66.

Poliakov, A. V., Svyatko, S. V., \& Stepanova, N. F. (2018). A Review of the Radiocarbon Dates for the Afanasyevo Culture (Central Asia): Shifting Towards the "Shorter" Chronology. Radiocarbon, doi:10.1017/RDC.2018.70.

Pre-print version. Visit http://digitalcommons.wayne.edu/humbiol/ after publication to acquire the final version. 
Pullyblank, E. G. (2000). The Hsiung-nu. Philologiae et historiae Turcicae fundamenta, 3, 52-75.

Raff, J., Cook, D. C., \& Kaestle, F. (2006). Tuberculosis in the New World: a study of ribs from Schild Mississippian population, West-Central Illinois. Memórias do Instituto Oswaldo Cruz, 101(suppl.II), 25-27.

Raff, J., Tackney, J., \& O’Rourke, D. H. (2010). South from Alaska: A Pilot aDNA Study of Genetic History on the Alaska Peninsula and the Eastern Aleutians. Human Biology, 82(5/6), 677-693.

Relethford, J. H. (2012). Human Population Genetics. Hoboken, NJ: Wiley-Blackwell.

Ricaut, F. X., Keyser-Tracqui, C., Cammaert, L., Crubézy, E., \& Ludes, B. (2004). Genetic Analysis and Ethnic Affinities from Two Scytho-Siberian Skeletons. American Journal of Physical Anthropology, 123, 351-360.

Rogers, L. L. (2016) Understanding Ancient Human Population Genetics of the Eastern Eurasian Steppe through Mitochondrial DNA Analysis: Central Mongolian Samples from the Neolithic, Bronze Age, Iron Age and Mongol Empire Periods. (Published Doctoral Dissertation). Indiana University, Bloomington.

Rudenko, S. I. (1970). Frozen Tombs of Siberia: The Pazyryk Burials of Iron-Age Horsemen. M. W. Thompson (Trans.). Berkeley, CA: University of California Press.

Sanger, F., Nicklen, S., \& Coulson, A. R. (1977). DNA sequencing with chain-terminating inhibitors. Proceedings of the National Academy of Sciences, USA 74(12), 5463-5467.

Schurr, T., \& Pipes, L. (2011). The Prehistory of Mongolian Populations as Revealed by Studies of Osteological, Dental, and Genetic Variation. L. W. Sabloff (Ed.). Mapping Mongolia: Situating Mongolia in the World from Geologic Time to the Present. (pp. 125-165). Philadelphia, PA: University of Pennsylvania Press.

Sukernik, R. I., Volodko, N. V., Mazunin, I. O., Eltsov, N. P., Dryomov, S.V., \& Starikovskaya, E. B. (2012). Mitochondrial Genome Diversity in the Tubalar, Even, and Ulchi: Contribution to Prehistory of Native Siberians and Their Affinities to Native Americans. American Journal of Physical Anthropology, 148, 123-138.

Svyatko, S. V., Schulting, R. J., Mallory, J., Murphy, E. M., Reimer, P. J., Khartanovich, V. I., Chistov, Y. K., \& Sablin, M. V. (2013). Stable isotope dietary analysis of prehistoric populations from the Minusinsk Basin, Southern Siberia, Russia: a new chronological framework for the introduction of millet to the eastern Eurasian steppe. Journal of Archaeological Science, 40, 3936-3945.

Torroni, A., Bandelt, H. J., Macaulay, V., Richards, M., Cruciani, F., Rengo, C., Martinez-Cabrera, V., Villems, R., Kivisild, T., Metspalu, E., Parik, J., Tolk, H. V., Tambets, K., Forster, P., Karger, B., Francalacci, P., Rudan, P., Janicijevic, B., Rickards, O., Savontaus, M. L., Huoponen, K., Laitinen, V., Koivumäki, S., Sykes, B., Hickey, E., Novelletto, A., Moral, P., Sellitto, D., Coppa, A., Al-Zaheri, N., Santachiara-Benerecetti, A. S., Semino, O., \& Scozzari, R. (2001). A Signal, from Human mtDNA, of Postglacial Recolonization in Europe. American Journal of Human Genetics, 69, 844-852.

Pre-print version. Visit http://digitalcommons.wayne.edu/humbiol/ after publication to acquire the final version. 
Tsybiktarov, A.D. 2002. Eastern Central Asia at the dawn of the Bronze Age: Issues in ethno-cultural history of Mongolia and the southern Trans-Baikal region in the late third-early second millennium BC. Archaeology, Ethnology, and Anthropology of Eurasia 3, 107-123.

van Oven, M. (2015). PhyloTree Build 17: Growing the human mitochondrial DNA tree. Forensic Science International: Genetics Supplement Series, 5, 9-11. http://linkinghub.elsevier.com/retrieve/pii/S1875176815302432. doi:10.1016/j.fsigss.2015.09.155.

Volkov, V. V. (1995). Early Nomads of Mongolia. Nomads of The Eurasian Steppes in The Early Iron Age. Berkeley, CA: Zinat Press. Retrieved from http://ehrafarchaeology.yale.edu/document?id=rl60-017

Volkov, V. V. (1980). Kurgany Afanas'evskogo tipa v Mongolii. Arkheologiin Sudlal 9, 13-16.

Vybornov, A. (2011). Time and paleoenvironment in the Neolithisation of the Povolzhye forest-steppe. Documenta Praehistorica, 38, 267-274.

Weissensteiner, H., Pacher, D., Kloss-Brandstätter, A., Forer, L., Specht, G., Bandelt, H. J., Kronenberg, F., Salas, A., \& Schönherr, S. (2016). HaploGrep 2: mitochondrial haplogroup classification in the era of high-throughput sequencing. Nucleic Acids Research, doi:10.1093/nar/gkw233.

Yao, Y. G., Kong, Q. P., Wang, C. Y., Zhu, C. L., \& Zhang, Y. P. (2004). Different Matrilineal Contributions to Genetic Structure of Ethnic Groups in the Silk Road Region in China. Molecular Biology and Evolution, 21(12), 2265-2280.

Zhao, Y. B., Zhang, Y., Zhang, Q. C., Li, H. J., Cui, Y. Q., Xu, Z., Jin, L., Zhou, H., \& Zhu, H. (2015). Ancient DNA Reveals That the Genetic Structure of the Northern Han Chinese Was Shaped Prior to 3,000 Years Ago. PLoS ONE, 10(5), e0125676. doi:10.1371/journal.pone.0125676. 


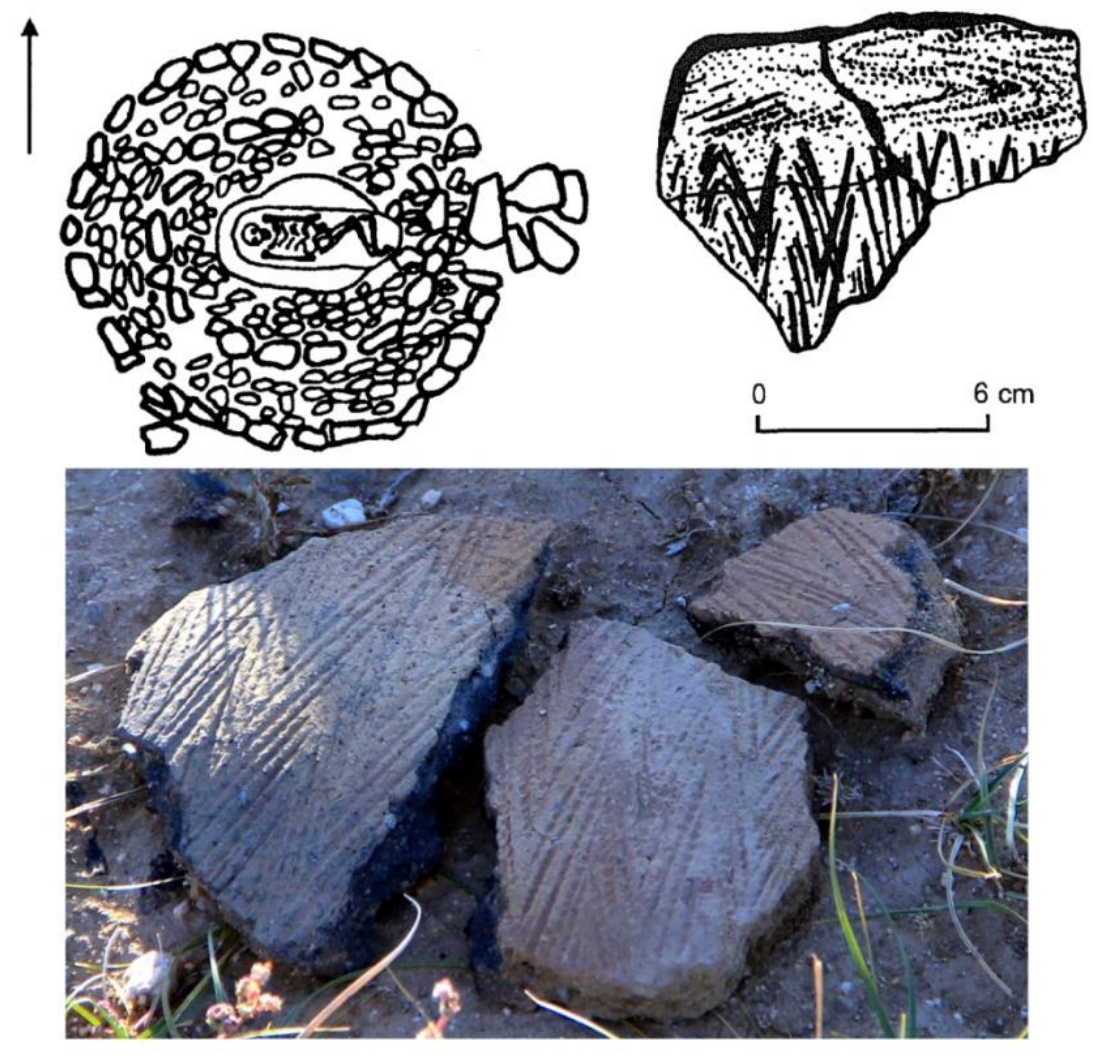

Figure 1. A schematic plan of Burial 3 from Shatar Chuluu and diagnostic pottery from in and around that context (after Tsybiktarov 2002:116, photo by Chunag Amartuvshin).

Pre-print version. Visit http://digitalcommons.wayne.edu/humbiol/ after publication to acquire the final version. 


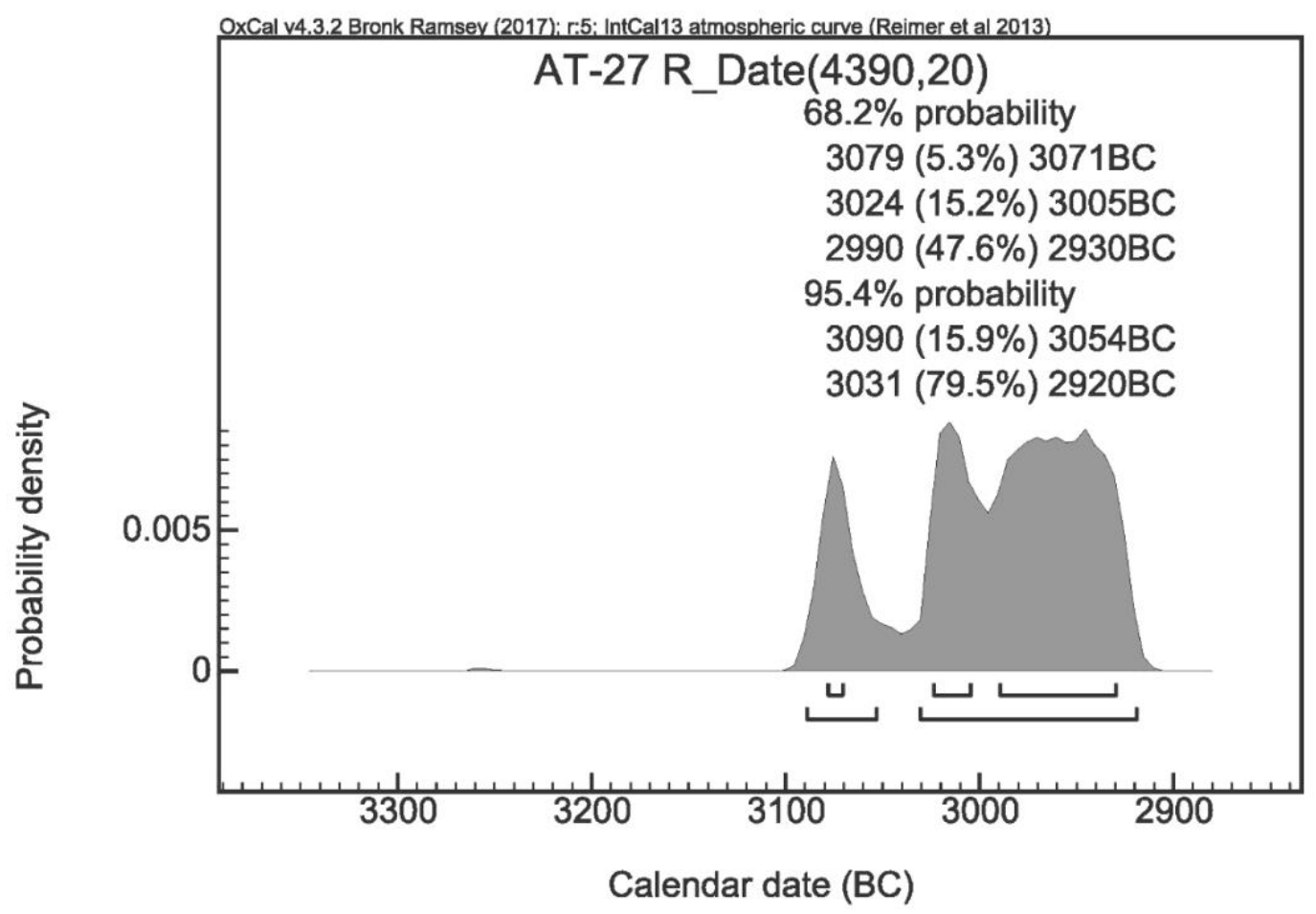

Figure 2. Radiocarbon dating results for skeletal sample AT27.

\begin{tabular}{|l|l|l|c|}
\hline Primer Name & Primer np & Primer Sequence & Amplicon Length \\
\hline 16038 forward & $16038-16055$ & 5'-AGCAGATTTGGGTACCAC-3' & \multirow{2}{*}{175} \\
\hline 16213 reverse & $16192-16213$ & 5'-CTGTACTTGCTTGTAAGCATGG-3' & \multirow{2}{*}{185} \\
\hline 16190 forward & $16190-16209$ & 5'-CCCCATGCTTACAAGCAAGT-3' & \multirow{2}{*}{157} \\
\hline 16375 reverse & $16356-16375$ & 5'-GTCATCCATGGGGACGAGAA-3' & \\
\hline 16266 forward & $16266-16288$ & 5'-CCCACTAGGATACCAACAAACC-3' & \\
\hline 16423 reverse & $16403-16423$ & 5'-ATTGATTTCACGGAGGATGG-3' & \\
\hline
\end{tabular}

Table 1. PCR Primers 


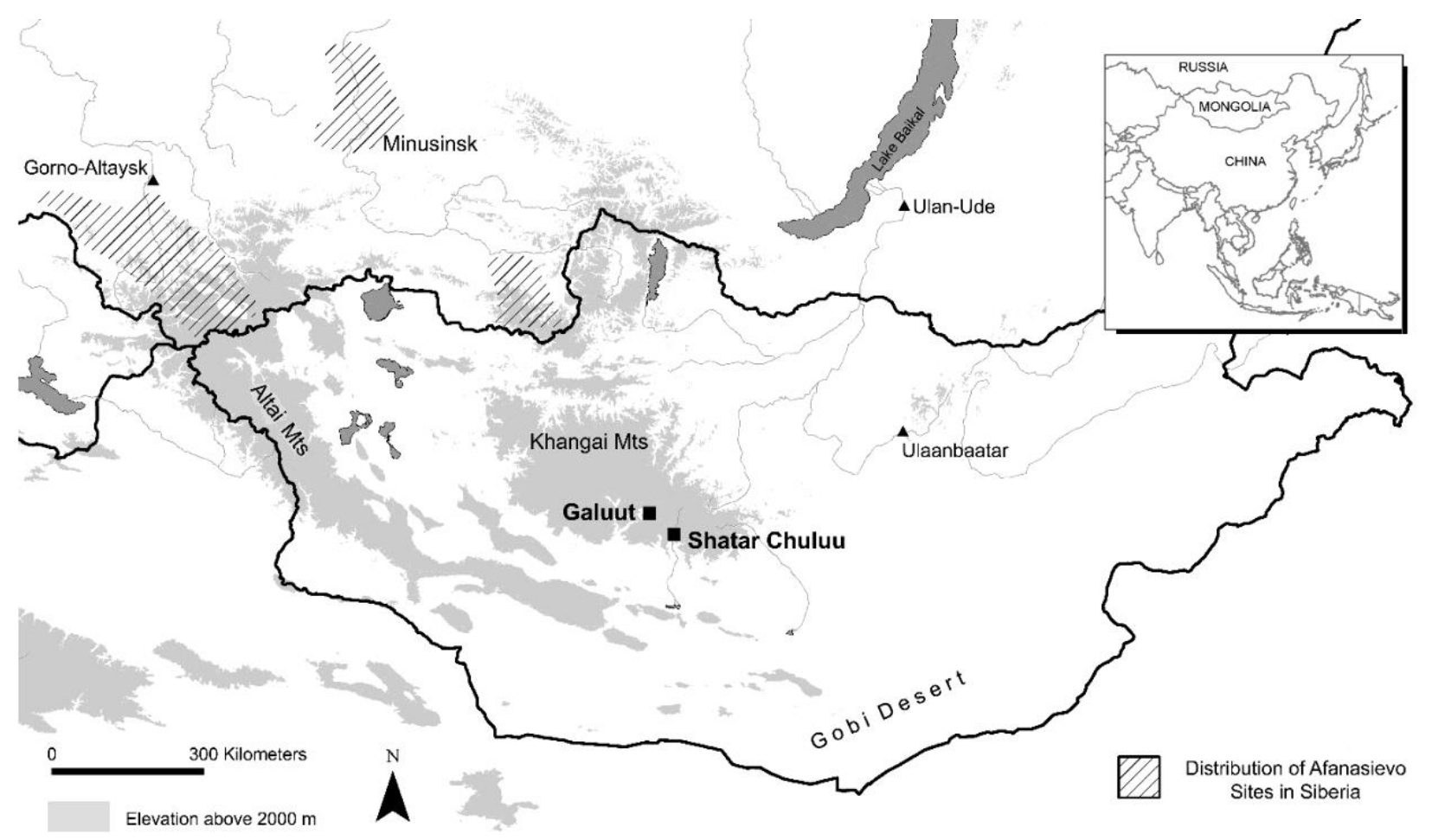

Map 1. Study excavation sites with reference to known Afanasievo archaeological culture locations.

Pre-print version. Visit http://digitalcommons.wayne.edu/humbiol/ after publication to acquire the final version. 